\title{
Sistem Informasi Pelanggan pada Bengkel Marno Jaya Motor
}

\author{
Khilyatin Ulin Fitri, Azizah Fatmawati \\ Program Studi Informatika \\ Universitas Muhammadiyah Surakarta (UMS) \\ Surakarta, Indonesia \\ khilyatinfitri72@gmail.com,af157@ums.ac.id
}

\begin{abstract}
Abstraksi-Sistem informasi pelanggan digunakan untuk membantu perusahaan dalam mengelola data setiap pelanggan yang ada baik itu yang baru ataupun lama. Seperti yang dialami pada Marno Jaya Motor yaitu terhambatnya proses pencarian data terhadap pelanggan lama ataupun dalam proses menambahkan data pada pelanggan lama dikarenakan masih dilakukan secara manual meskipun sudah menggunakan bantuan aplikasi yaitu Microsoft Excel dan Microsoft Word. Bahkan masih menggunakan media kertas sebagai tempat penyimpanan data yang menyebabkan banyak waktu terbuang karena harus mencari dan memilah terlebih dahulu satu persatu. Tujuan penelitian ini adalah ingin mengembangkan sistem informasi pelanggan yang akan membantu kinerja Marno Jaya Motor dalam mengelola data setiap pelanggannya. Metode yang digunakan dalam pengembangan sistem informasi ini adalah metode wawancara, metode observasi, metode dokumentasi dan metode waterfall yang meliputi analisis kebutuhan, desain, pemrograman, uji coba, dan implementasi. Hasil dari pengembangan berupa sistem informasi pelanggan pada bengkel Marno Jaya Motor dapat membantu karyawan dalam mengelola data dengan waktu yang efektif dan efisien. Berdasarkan pengujian black box, sistem dapat berjalan sesuai dengan fungsinya. Sedangkan hasil pengujian usability memperoleh ratarata nilai 68,3 yang dapat disimpulkan bahwa nilai sistem berada pada kategori baik dan dapat diterima pengguna serta memenuhi karakteristik usability.
\end{abstract}

Katakunci-metode waterfall, pelanggan, sistem informasi

\section{Pendahuluan}

Sistem informasi adalah suatu sistem dalam suatu organisasi yang mendukung fungsi operasi yang bersifat manajerial dengan kegiatan strategi dari suatu organisasi untuk dapat menyediakan kepada pihak luar dengan informasi yang diperlukan untuk pengambilan keputusan [1]. Sistem informasi pelanggan digunakan untuk membantu perusahaan dalam mengelola data setiap pelanggan yang ada baik itu yang baru ataupun lama. Seperti yang dialami pada Marno Jaya Motor yaitu terhambatnya dalam proses mengelola data setiap pelanggannya.

Marno Jaya Motor merupakan bengkel khusus mobil yang memiliki spesifikasi Electronic Fuel Injection (EFI) dengan semua jenis mobil. Marno Jaya Motor sendiri bergerak pada bidang jasa baik itu memberikan pelayanan maupun menjual sparepart dan oli. Proses mengelola data, bengkel masih mengerjakan secara manual dengan media kertas meskipun sudah menggunakan bantuan aplikasi yaitu Microsoft Word dan Microsoft Excel [2]. Terkadang banyaknya data yang disimpan menyebabkan terjadinya penumpukan sehingga ada beberapa data yang rangkap bahkan hilang dan memerlukan waktu yang cukup lama dalam proses pencarian datanya [3].

Software Development Life Cycle (SDLC) merupakan metode pengembangan rekayasa perangkat lunak yang memiliki sifat seperti air terjun yaitu harus dikerjakan secara berurutan. SDLC memiliki beberapa model salah satunya metode waterfall, yaitu metode terbaik dan paling banyak digunakan oleh pengembang dimana harus dikerjakan secara berurutan dan hasil dari setiap tahap menjadi sebuah masukan untuk tahapan berikutnya [4].

Berdasarkan pembahasan di atas, maka penulis menggunakan metode waterfall untuk mengembangkan sistem informasi yang akan membantu kinerja Marno Jaya Motor dalam mengelola data setiap pelanggannya supaya menjadi lebih efektif dan efisien.

\section{METODE}

\section{A. Alat dan Bahan}

Dalam proses pengembangan sistem informasi pelanggan ini, penulis menggunakan beberapa alat dan bahan. Adapun alat-alat yang dipergunakan dalam proses pengembangan, baik itu hardware ataupun software dapat dilihat pada Tabel 1. Adapun bahan-bahan yang dipergunakan dalam proses pengembangan yaitu seluruh data pelanggan yang ada pada Marno Jaya Motor sejak awal berdirinya. Data diperoleh dengan wawancara, observasi dan dokumentasi secara langsung melalui pemilik ataupun karyawan yang diberikan wewenang untuk memberikan data tersebut. 
TABEL 1. PERALATAN YANG DIGUNAKAN

\begin{tabular}{|c|l|l|}
\hline No & \multicolumn{1}{|c|}{ Nama Alat } & \multicolumn{1}{c|}{ Spesifikasi } \\
\hline 1 & Windows & Windows 10 (64-bit) \\
\hline 2 & MySQL (MariaDB) & Version 5.6.15 \\
\hline 3 & Microsoft Visio & Version 2016 \\
\hline 4 & Microsoft Word & Version 2016 \\
\hline 5 & Microsoft Excel & Version 2016 \\
\hline 6 & Sublime Text Editor & Version 3 (64-bit) \\
\hline
\end{tabular}

\section{B. Prosedur}

Metode yang digunakan dalam penelitian ini antara lain:

a. Lokasi Penelitian

Penulis mengadakan penelitian di Marno Jaya

Motor yang bertempat di Jajar, Laweyan, Surakarta.

b. Metode Pengumpulan Data

1.Metode Wawancara

Metode wawancara merupakan metode pengumpulan data atau informasi berdasarkan hasil yang diperoleh secara langsung dari pihak yang bersangkutan dengan cara tanya jawab [5]. Kemudian ditampung dan dijadikan sebagai data informasi.

2.Metode Observasi

Metode observasi merupakan metode pengumpulan data berdasarkan pengamatan secara langsung terhadap objek yang akan diteliti dengan menggunakan panca indera mata dan dibantu dengan panca indera lainnya [5].

3.Metode Dokumentasi

Metode dokumentasi merupakan metode pengumpulan data berdasarkan data yang dimiliki oleh bengkel Marno Jaya Motor.

\section{Pengembangan Sistem}

Metode yang digunakan dalam pengembangan sistem ini adalah metode waterfall. Metode waterfall merupakan sebuah proses perancangan yang sering digunakan dalam proses pengembangan rekayasa perangkat lunak, dimana kemajuan dipandang seperti air terjun yaitu mengalir terus ke bawah dengan melalui beberapa tahapan [4]. Adapun tampilan metode waterfall terdapat pada Gambar 1 .

Terdapat 5 tahapan dalam proses pengembangan sistem informasi pelanggan ini yaitu analisis kebutuhan, desain (perancangan sistem), pemrograman, uji coba, dan implementasi.

1. Analisis Kebutuhan

Tahapan analisis kebutuhan ini dilakukan dengan menganalisis dari kebutuhan hardware, software dan kebutuhan proses bisnis.

a.Analisis Kebutuhan Hardware
Perangkat keras (hardware) yang digunakan untuk mendukung proses sistem informasi pada bengkel Marno Jaya Motor adalah komputer (PC) untuk mengelola data setiap pelanggannya.

b.Analisis Kebutuhan Software

Perangkat lunak (software) yang digunakan untuk mendukung proses sistem informasi antara lain :

- Operating System (OS) menggunakan Windows (XP, 7, 8, 10) yang mendukung aplikasi XAMPP dan web browser yaitu Mozilla Firefox atau Google Chrome.

- Aplikasi XAMPP, yang digunakan sebagai tulang punggung server sistem informasi.

- Mozilla Firefox dan Google Chrome yang digunakan minimal versi 60 .

c. Analisis Kebutuhan Proses Bisnis

Tahapan analisis kebutuhan proses bisnis dilakukan untuk mengidentifikasi siapa yang akan menggunakan sistem ini serta apakah sistem sangat dibutuhkan oleh pengguna [6]. Sistem ini akan digunakan oleh karyawan bengkel Marno Jaya Motor guna membantu dalam proses pencatatan semua pelanggan yang melakukan servis di bengkel tersebut.

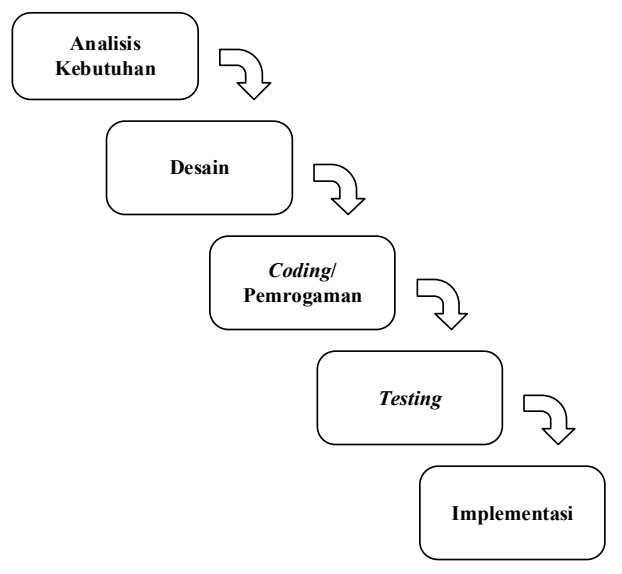

Gambar 1. Metode Waterfall [4]

2. Desain (Perancangan Sistem)

a. Use Case Diagram

Karyawan dan pemilik Marno Jaya Motor bertindak sebagai aktor yang dapat melakukan kegiatan yang berhubungan dengan pengelolaan sistem informasi seperti melihat, menambah, menghapus dan mencetak laporan. Adapun rincian dari use case diagram terdapat pada Gambar 2 . 


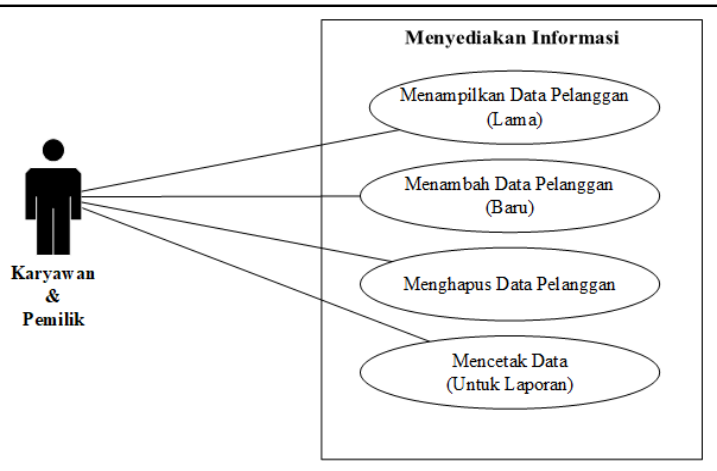

Gambar 2. Use Case Diagram Karyawan dan Pemilik

\section{b.Activity Diagram}

Pemilik dan Karyawan dapat melakukan proses input (memasukkan) data pelanggan yang akan di proses oleh sistem sebagai permintaan untuk melakukan input data. Kemudian, sistem akan menyimpan data pada database setelah melakukan proses memasukkan data. Setelah memasukkan dan menyimpan data maka sistem akan menampilkannya. Adapun tampilan dapat dilihat pada Gambar 3. Selain dapat melakukan proses input dan melihat data, pemilik dan karyawan dapat mengubah data. Adapun tampilan activity diagram dapat dilihat pada Gambar 4. Serta dapat menghapus dan mencetak data yang akan digunakan sebagai laporan. Adapun tampilan activity diagram terdapat pada Gambar 5 dan Gambar 6.

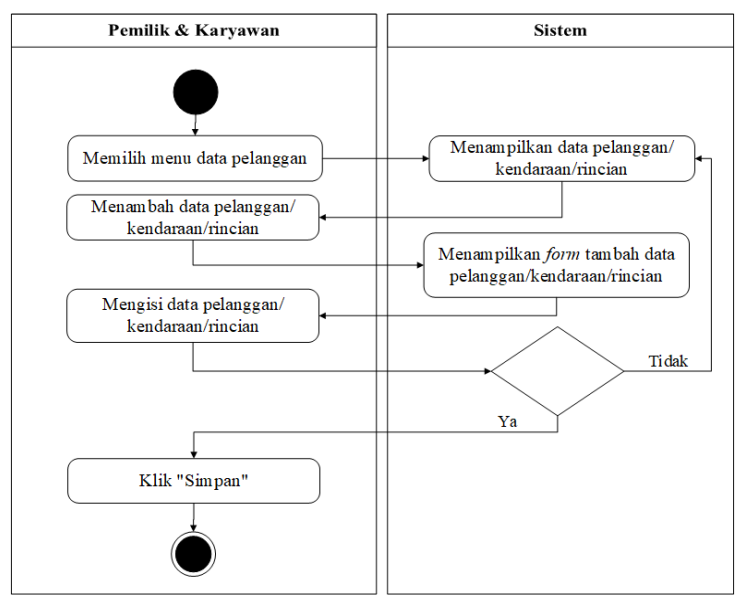

Gambar 3. Activity Diagram Menampilkan dan Menambahkan Data

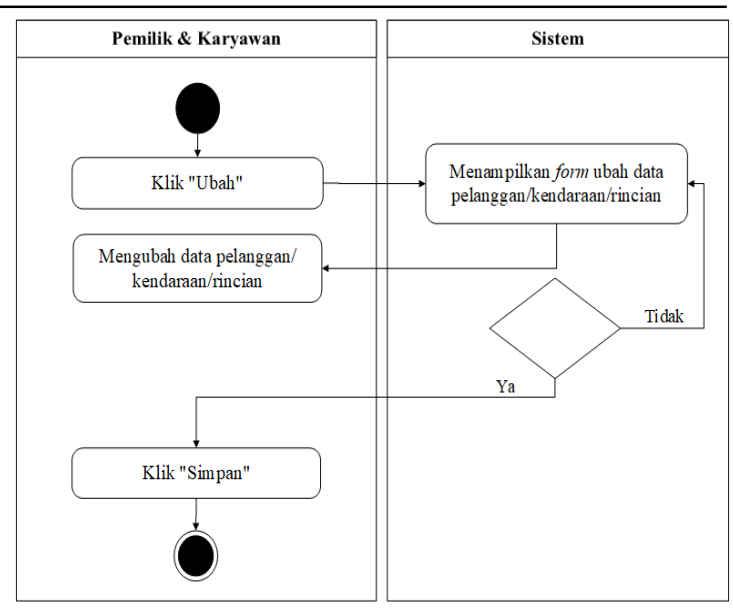

Gambar 4. Activity Diagram Mengubah Data

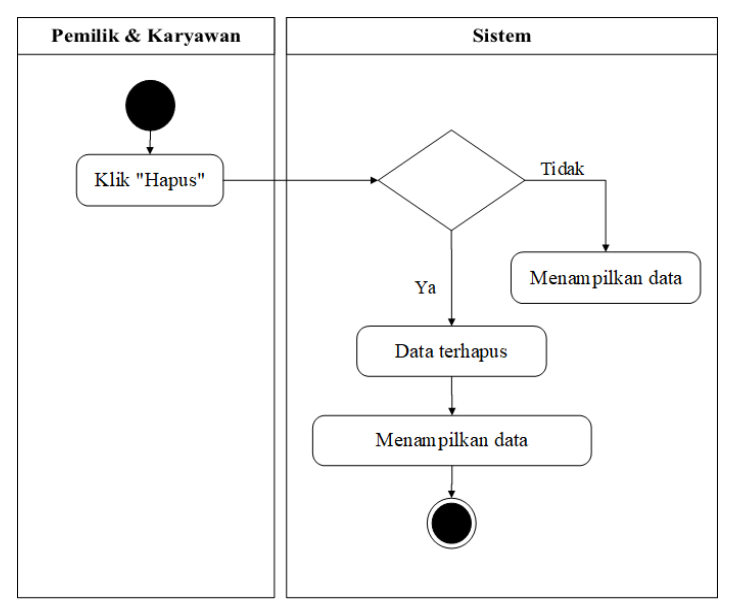

Gambar 5. Activity Diagram Menghapus Data

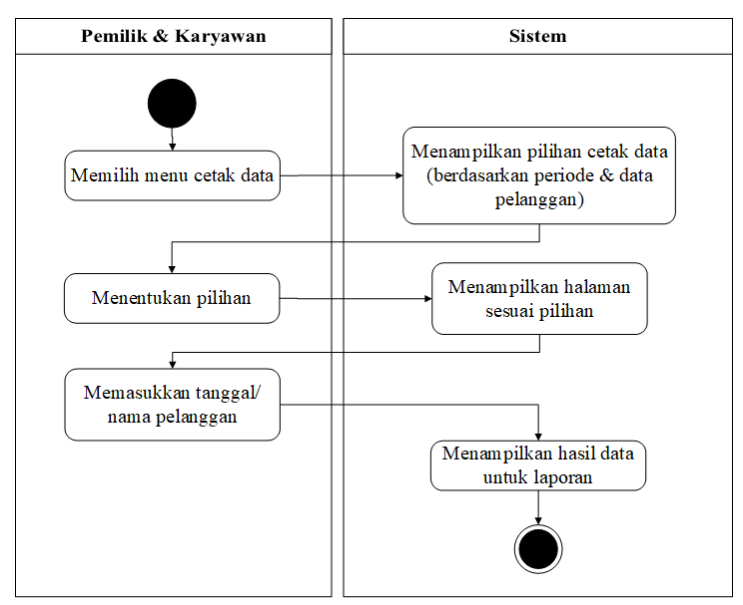

Gambar 6. Activity Diagram Mencetak Data 


\section{Pemrograman}

Tahapan pemrograman ini, penulis membutuhkan software ataupun hardware tertentu dalam mendukung proses pengembangannya. Seperti yang dijelaskan pada bab metode bagian alat dan bahan.

Tahapan ini akan membuat database yang berfungsi sebagai tempat penyimpanan data. Database yang dibuat harus sesuai tahapan sebelumnya yaitu merancang sistem. Struktur database yang akan digunakan adalah struktur tabel user, struktur tabel pelanggan, struktur tabel rincian, dan struktur tabel kendaraan.

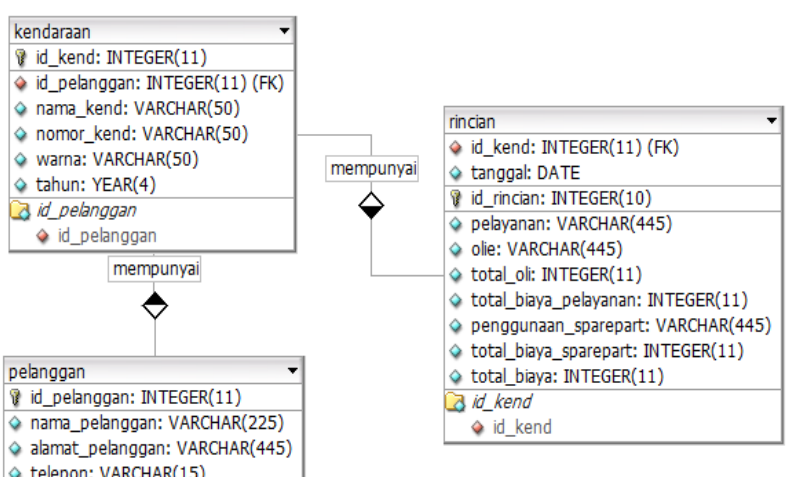

Gambar 7. ER Diagram

Berdasarkan ER Diagram pada Gambar 7, struktur tabel user terdiri dari id sebagai primary key, username, dan password yang berfungsi untuk menyimpan data yang akan digunakan sebagai kunci utama masuk ke dalam sistem yang akan dikembangkan. Kedua, struktur tabel pelanggan terdiri dari id pelanggan sebagai primary key, nama pelanggan, alamat, dan nomor telepon berfungsi untuk menyimpan data setiap pelanggan yang ada di Marno Jaya Motor. Ketiga, struktur tabel rincian terdiri dari id kendaraan sebagai foreign key yang akan menghubungkan antara tabel rincian dengan tabel kendaraan, tanggal masuk kendaraan, id rincian sebagai primary key, pelayanan, total biaya pelayanan, olie yang digunakan, total biaya olie, sparepart yang digunakan, total biaya sparepart, dan total biaya keseluruhan. Tabel rincian digunakan untuk menyimpan seluruh riwayat pelayanan yang pernah diberikan beserta biayanya. Terakhir, struktur tabel kendaraan yang terdiri dari id kendaraan sebagai primary key, id pelanggan sebagai foreign key yang akan menghubungkan antara tabel kendaraan dengan tabel pelanggan, nama, nomor, warna, dan tahun kendaraan berfungsi untuk menyimpan data setiap kendaraan yang dimiliki pelanggan Marno Jaya Motor.

\section{Uji Coba}

Tahapan uji coba ini dilakukan oleh pengembang ataupun pengguna (user) yang akan menggunakannya dengan metode Black Box Testing dan pengujian usability. Uji coba ini bertujuan sebagai penilaian apakah sistem yang dikembangkan dapat dinyatakan berhasil atau gagal dan untuk memperlihatkan keakuratan fitur utama di dalam sistem [7]. Sedangkan pengujian usability atau System Usability Scale (SUS) merupakan salah satu model kuisioner dengan memberikan 10 pertanyaan yang digunakan untuk memperlihatkan apakah sistem mudah dipahami dan berjalan dengan semestinya oleh pengguna.

5. Implementasi

Tahapan ini berarti sistem yang dikembangkan telah lolos atau berhasil dari uji coba dan siap diterapkan atau diimplementasikan dalam bengkel tersebut. Tahapan ini akan bersamaan dilakukannya perawatan (maintenance) untuk mencegah terjadinya kerusakan ataupun gangguan selama digunakan. Perawatan tersebut akan dilakukan secara rutin dan berkala.

\section{HASIL DAN PEMBAHASAN}

Hasil dari penelitian ini merupakan suatu sistem informasi pelanggan berbasis website yang dapat digunakan dalam mengelola data pelanggan pada bengkel Marno Jaya Motor dan mencetak laporan berdasarkan periode tertentu. Sistem informasi pelanggan ini dikembangkan menggunakan bahasa pemograman PHP dan MySQL sebagai database.

\section{a. Hasil Penelitian}

Halaman Login merupakan halaman yang digunakan untuk melakukan verifikasi dan hanya dapat diakses oleh admin yaitu karyawan yang diberikan kewenangan untuk mengelola data pelanggan. Adapun tampilan halaman login ditunjukkan pada Gambar 8.

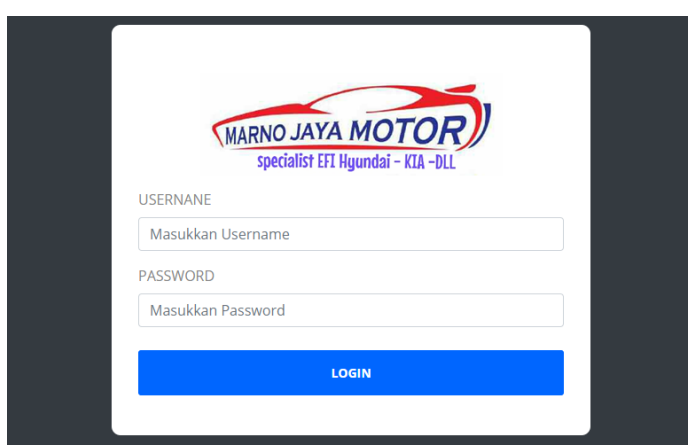

Gambar 8. Halaman Login 
Halaman utama (home) merupakan halaman yang pertama kali tampil ketika login diverifikasi dan disajikan tampilan yang terdapat menu home, data pelanggan, cetak laporan dan pengguna. Halaman utama (home) berisi informasi mengenai sistem yang telah dikembangkan. Adapun tampilan halaman utama (home) ditunjukkan pada Gambar 9.

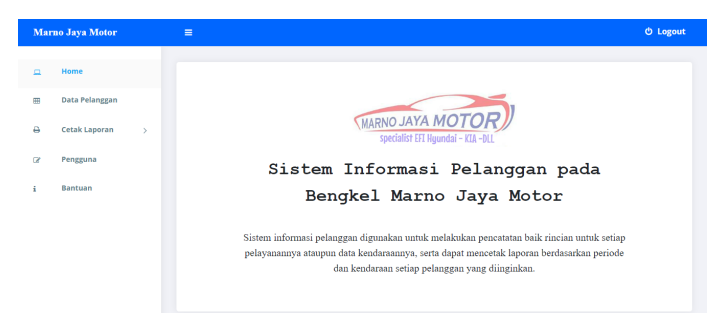

Gambar 9. Halaman Utama (Home)

Halaman data pelanggan merupakan halaman yang digunakan admin untuk melihat, menambah, mengubah dan menghapus data baik data pelanggan, data kendaraan, dan data rincian setiap kendaraan. Adapun tampilan halaman data pelanggan ditunjukkan pada Gambar 10 .

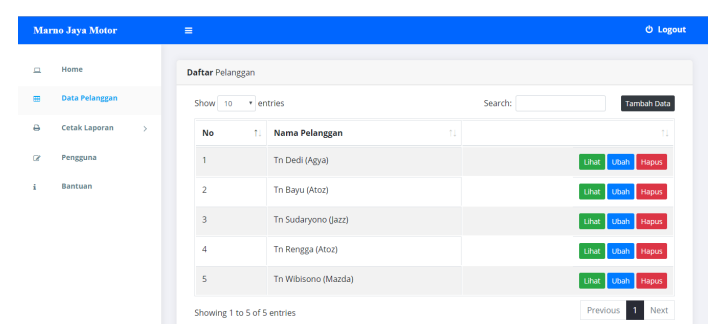

Gambar 10. Halaman Data Pelanggan

Halaman cetak laporan merupakan halaman yang digunakan admin untuk mencetak laporan baik berdasarkan periode tertentu ataupun berdasarkan data setiap pelanggan. Halaman cetak laporan berdasarkan periode terdapat masukan yang digunakan untuk menentukan tanggal awal dan akhir data yang ingin dicetak. Sedangkan halaman cetak laporan berdasarkan data setiap pelanggan terdapat masukan yang menampilkan daftar pelanggan dan daftar kendaraan yang dimiliki setiap pelanggannya. Adapun tampilan salah satu halaman cetak laporan ditunjukkan pada Gambar 11.

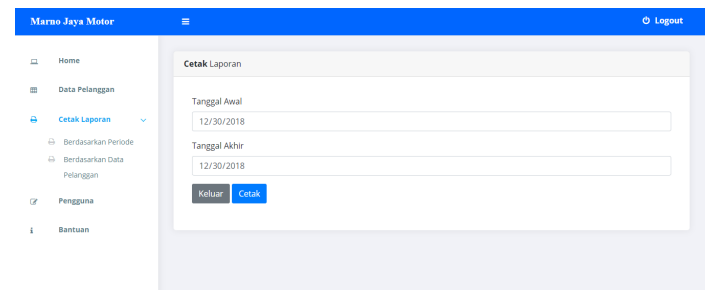

Gambar 11. Halaman Cetak Laporan Berdasarkan Periode

Halaman pengguna merupakan halaman yang digunakan admin untuk mengubah username dan password untuk menghindari adanya pengguna lain masuk tanpa seijin admin. Adapun tampilan halaman pengguna ditunjukkan pada Gambar 12.

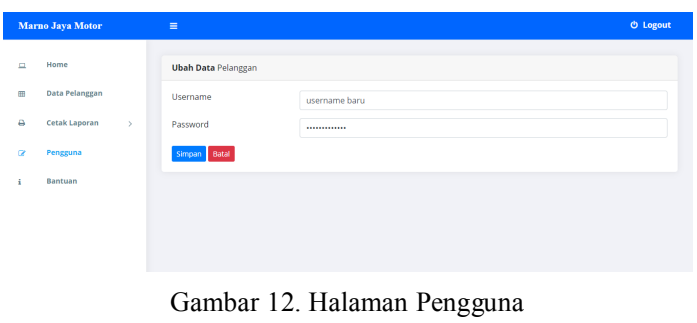

Halaman bantuan merupakan halaman yang menampilkan panduan (cara penggunaan) bagi admin untuk membantu dalam mengoperasikan sistem. Adapun tampilan halaman bantuan bantuan ditunjukkan pada Gambar 13.

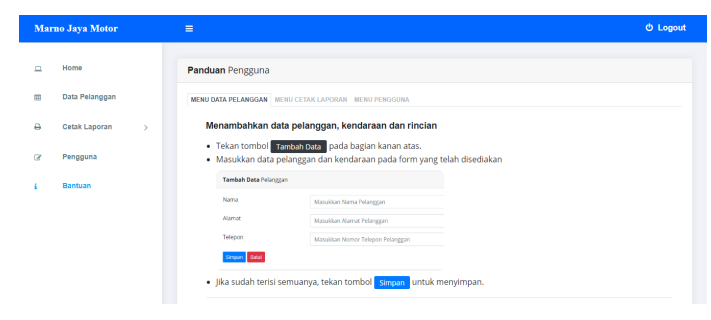

Gambar 13. Halaman Bantuan

Hasil laporan yang telah dicetak melalui halaman cetak laporan dan laporan dapat disimpan dalam bentuk format pdf ataupun dicetak jika sudah terkoneksi dengan mesin pencetak. Adapun tampilan salah satu hasil laporan ditunjukkan pada Gambar 14.

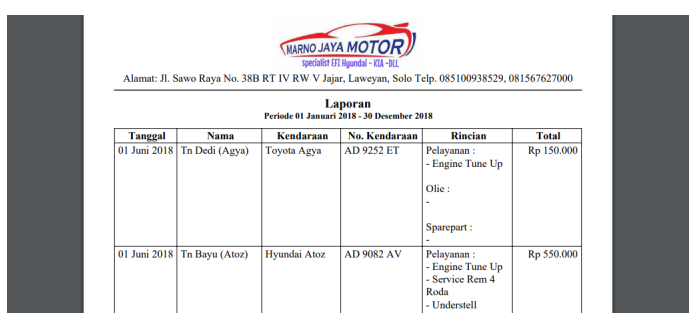

Gambar 14. Hasil Laporan Berdasarkan Periode Tertentu

b. Pengujian Black Box

Pengujian black box dilakukan agar dapat mengetahui apakah sistem yang telah dikembangkan sudah berjalan 
dengan baik atau gagal dalam menjalankan fungsinya. Pengujian dilakukan dengan cara diimplementasikan pada salah satu laptop atau komputer dan web browser Google Chrome atau Mozilla Firefox. Adapun hasil pengujian black box sistem informasi pelanggan pada bengkel Marno Jaya Motor tertera pada Tabel 2.

TABEL 2. HASIL PENGUJIAN BLACK BOX

\begin{tabular}{|c|c|c|c|c|}
\hline No & Penguji & Kondisi Penguji & Harapan & Hasil \\
\hline 1 & Login & $\begin{array}{l}\text { 1. Usemame dan password } \\
\text { benar. } \\
\text { 2. Usemame dan password salah. }\end{array}$ & $\begin{array}{l}\text { 1. Sistem berhasil masulk ke } \\
\text { halaman menu sesuai hak akses. } \\
\text { 2. Sistem berhasil kembali ke } \\
\text { halaman login apabila usemame } \\
\text { dan password salah }\end{array}$ & Valid \\
\hline 2 & Logout & Keluar dari aplikasi & $\begin{array}{l}\text { Sistem dapat keluar dari aplikasi } \\
\text { dan kembali ke halaman login }\end{array}$ & Valid \\
\hline 3 & $\begin{array}{l}\text { Menampilikan } \\
\text { Halaman utama }\end{array}$ & $\begin{array}{l}\text { Menampilkan halaman utama } \\
\text { setelah admin berhasil melakukan } \\
\text { login }\end{array}$ & $\begin{array}{l}\text { Sistem berhasil menampilkan } \\
\text { halaman awal }\end{array}$ & Valid \\
\hline 4 & $\begin{array}{l}\text { Menampilkan } \\
\text { halaman data } \\
\text { pelanggan, } \\
\text { kendaraan dan } \\
\text { rincian } \\
\end{array}$ & $\begin{array}{l}\text { Menampilkan daftar pelanggan, } \\
\text { data kendaraan dan daftar rincian } \\
\text { pelayanan setiap kendaraan }\end{array}$ & $\begin{array}{l}\text { Sistem berhasil menampillkan } \\
\text { daftar pelanggan yang pernah } \\
\text { melakukan servis, data } \\
\text { kendaraan dan rincian pelayanan }\end{array}$ & Valid \\
\hline 5 & $\begin{array}{l}\text { Mengubah data } \\
\text { pelanggan, } \\
\text { kendaraan dan } \\
\text { rincian pelayanan }\end{array}$ & $\begin{array}{l}\text { Mengubah data pelanggan, } \\
\text { kendaraan dan rincian pelayanan } \\
\text { pada form ubah data pelanggan }\end{array}$ & $\begin{array}{l}\text { Sistem berhasil mengubah data } \\
\text { pelanggan, kendaraan, dan rincian } \\
\text { pelayanan }\end{array}$ & valid \\
\hline 6 & $\begin{array}{l}\text { Menghapus data } \\
\text { pelanggan, } \\
\text { kendaraan dan } \\
\text { rincian pelayanan }\end{array}$ & $\begin{array}{l}\text { Menghapus data pelanggan, } \\
\text { kendaraan dan rincian pelayanan }\end{array}$ & $\begin{array}{l}\text { Sistem berhasil menghapus data } \\
\text { pelanggan, kendaraan dan rincian } \\
\text { pelayanan }\end{array}$ & Valid \\
\hline 7 & $\begin{array}{l}\text { Menambah data } \\
\text { pelanggan baru, } \\
\text { kendaraan, dan } \\
\text { rincian pelayanan } \\
\end{array}$ & $\begin{array}{l}\text { Menambah data pelanggan baru, } \\
\text { kendaraan dan rincian pelayanan } \\
\text { pada form tambah data kendaraan }\end{array}$ & $\begin{array}{l}\text { Sistem berhasi menambahkan } \\
\text { data pelanggan, kendaraan dan } \\
\text { rincian pelayanan (sesuai yang } \\
\text { diinginkan) }\end{array}$ & Valid \\
\hline 8 & Mencetak laporan & $\begin{array}{l}\text { Mencetak laporan berdasarkan } \\
\text { periode dan berdasark an data } \\
\text { pelanggan }\end{array}$ & $\begin{array}{l}\text { Sistem berhasil mencetak laporan } \\
\text { sesuai periode yang diinginkan } \\
\text { dan sesuai dengan data pelanggan } \\
\text { yang dipilih }\end{array}$ & Valid \\
\hline 9 & $\begin{array}{l}\text { Mengubah } \\
\text { usemame dan } \\
\text { password admin }\end{array}$ & $\begin{array}{l}\text { Mengubah usemame dan } \\
\text { password admin }\end{array}$ & $\begin{array}{l}\text { Sistem berhasil mengubah } \\
\text { usemame dan password admin }\end{array}$ & Valid \\
\hline 10 & $\begin{array}{l}\text { Menampilkan } \\
\text { halaman bantuan }\end{array}$ & $\begin{array}{l}\text { Menampilkan halaman bantuan } \\
\text { yang berisi panduan (cara } \\
\text { mengoperasikan) sistem bagi } \\
\text { admin }\end{array}$ & Sistem berhasil menampillkan & Valid \\
\hline
\end{tabular}

\section{c. Pengujian Usability}

Tahapan selanjutnya adalah pengujian usability, pada tahapan ini akan melibatkan 3 karyawan bengkel Marno Jaya Motor sebagai responden guna mengetahui pendapat atau penilaian dari pengguna mengenai sistem yang telah dikembangkan melalui model kuesioner SUS (System Usability Scale). Model kuesioner SUS menyediakan pilihan jawaban antara 1-5 yang terdiri dari sangat tidak setuju (STS), tidak setuju (TS), netral (Netral), setuju (S), dan sangat setuju (SS) [8]. Hasil perhitungan dengan pertanyaan bernomor ganjil dijelaskan pada Persamaan 1, untuk pertanyaan bernomor genap dijelaskan pada Persamaan 2, perhitungan hasil akhir dijelaskan pada Persamaan 3 dan hasil dari pengujian usability dapat dilihat pada Tabel 3 .

Ganjil = Bobot Jawaban -1

Genap $=5-$ Bobot Jawaban

Hasil Akhir = Jumlah Ganjil \& Genap x 2,5
Hasil akhir memiliki rentang nilai antara 0-100 dengan interval nilai yang dibagi menjadi 5 kategori yaitu sangat buruk dengan rentang nilai 0-19,99, buruk dengan rentang nilai 20-39,99, cukup dengan rentang nilai 40-59,99, baik dengan rentang nilai 60-79,99, dan sangat baik dengan rentang nilai 80-100. Apabila sistem mendapatkan nilai akhir rata-rata lebih dari sama dengan 60 maka sistem telah memenuhi karakteristik usability [9].

TABEL 3. HASIL PENGUJIAN USABILITY

\begin{tabular}{|c|c|c|c|c|}
\hline \multirow{2}{*}{ No } & \multirow{2}{*}{ Pertanyaan } & \multicolumn{3}{|c|}{ Responden } \\
\hline & & 1 & 2 & 3 \\
\hline 1 & Saya pikir akan sering menggunakan sistem ini. & 5 & 5 & 5 \\
\hline 2 & Saya merasa sistem ini terlalu rumit. & 1 & 3 & 2 \\
\hline 3 & Saya merasa sistem ini mudah untuk digunakan. & 4 & 3 & 4 \\
\hline 4 & $\begin{array}{l}\text { Saya merasa memerlukan bantuan dari orang teknis dalam } \\
\text { menggunakan sistem ini. }\end{array}$ & 1 & 4 & 4 \\
\hline 5 & $\begin{array}{l}\text { Saya merasa jika fungsi pada sistem ini sudah terintegrasi } \\
\text { dengan baik. }\end{array}$ & 4 & 4 & 5 \\
\hline 6 & $\begin{array}{l}\text { Saya merasa banyak hal yang tidak konsisten terdapat pada } \\
\text { sistem ini. }\end{array}$ & 2 & 3 & 2 \\
\hline 7 & $\begin{array}{l}\text { Saya merasa banyak pengguna yang dapat mempelajari sistem } \\
\text { ini dengan cepat. }\end{array}$ & 3 & 4 & 5 \\
\hline 8 & Saya merasa sistem ini sangat tidak praktis saat digunakan. & 3 & 2 & 1 \\
\hline 9 & Saya sangat yakin dapat menggunakan sistem ini. & 5 & 4 & 3 \\
\hline 10 & $\begin{array}{l}\text { Saya memerlukan belajar terlebih dahulu sebelum } \\
\text { menggunakan sistem ini. }\end{array}$ & 4 & 4 & 5 \\
\hline & $\begin{array}{rr} & \text { Jumlah } \\
\end{array}$ & 32 & 36 & 36 \\
\hline & Nilai & 75,0 & 60,0 & 70,0 \\
\hline & Rata-rata Nilai & & 68,3 & \\
\hline
\end{tabular}

Berdasarkan hasil dari pengujian usability diperoleh rata-rata nilai sebesar 68,3 yang dapat disimpulkan bahwa nilai sistem berada pada kategori baik dan dapat diterima pengguna serta memenuhi karakteristik usability.

\section{PENUTUP}

\section{A. Kesimpulan}

Aplikasi sistem informasi pelanggan pada bengkel Marno Jaya Motor telah selesai dikembangkan dan dinyatakan mampu membantu kinerja karyawan dalam mengelola data pelanggan menjadi lebih efektif dan efisien. Berdasarkan hasil pengujian black box, sistem dapat berjalan sesuai dengan fungsinya. Sedangkan hasil ratarata nilai dari pengujian usability memperoleh 68,3 yang dapat disimpulkan bahwa sistem berada pada kategori baik dan dapat diterima pengguna.

\section{B. Saran}

Penelitian selanjutnya diharapkan mampu mengembangkan aplikasi menjadi lebih luas cakupannya seperti menambahkan fitur untuk mengelola data bagian gudang atau mengembangkannya ke dalam aplikasi 
berbasis mobile sehingga mudah untuk digunakan dimanapun dan kapanpun.

\section{Daftar Pustaka}

[1] H. Antonio and N. Safriadi, "Rancang Bangun Sistem Informasi Administrasi Informatika ( SI-ADIF )," J. ELKHA, vol. 4, no. 2, pp. $12-15,2012$.

[2] S. T. Safitri and D. Supriyadi, "Rancang Bangun Sistem Informasi Praktek Kerja Lapangan Berbasis Web dengan Metode Waterfall," $J$. INFOTEL - Inform. Telekomun. Elektron., vol. 7, no. 1, p. 69, May 2015.

[3] Y. Nugraheni and Sukadi, "Perancangan Sistem Rekapitulasi Pengunjung Pada Unit Pelaksana Teknis Puskesmas Sukorejo Kecamatan Sudimoro," IJNS - Indones. J. Netw. Secur., vol. 4, no. 3, Dec. 2013.
[4] S. Balaji and M. S. Murugaiyan, "WATERFALL Vs V-MODEL Vs AGILE : A COMPARATIVE STUDY ON SDLC,” vol. 2, no. 1, pp. 26-30, 2012.

[5] L. J. Moleong and T. Sujarman, Metodologi penelitian kualitatif. Remaja Karya, 1989.

[6] S. Nurhayati, "Analisis Kebutuhan Proses Bisnis Menggunakan Metode Kano,” Jur. Tek. Komput. Fak. Tek. dan Ilmu Komput. Univ. Komput. Indones. Quaschning, 2005., 2014.

[7] W. D. Prasetyo and A. Fatmawati, "Sistem informasi inventaris desa berbasis web," Universitas Muhammadiyah Surakarta, 2017.

[8] K. C. Brata and A. H. Brata, "Pengembangan Aplikasi Mobile Augmented Reality untuk Mendukung Pengenalan Koleksi Museum," $J$. Teknol. Inf. dan Ilmu Komput., vol. 5, no. 3, p. 347, Aug. 2018.

[9] A. Tribowo, D. S. Rusdianto, and H. Nurwarsito, "Pembangunan Sistem Pengelolaan Restoran Terintegrasi Dengan Pengujian Kualitas Berbasis ISO 9126," Nov. . 